\section{Long-Distance Genome Walking Using the Long and Accurate Polymerase Chain Reaction}

BioTechniques 24:398-400 (March 1998)

Many methods using polymerase chain reaction (PCR) have been developed and modified to isolate an unknown DNA sequence adjacent to a known sequence; these are collectively called gene-walking methods (1,4-9). However, their usage has been restricted because most previous methods had practical problems, including low sensitivity, low efficiency (small probability of success) and/or are laborious with multiple steps. Furthermore, the extended nucleotide stretch is usually short in length. Except for laborious inversion PCR (up to 2-kb extension; Reference 8), most methods produce PCR products only 200-800 nucleotides in length.

To increase the length and the accuracy of walking products, we have applied the long and accurate PCR (LA$\mathrm{PCR})$ technique $(2,3)$ in the new method. Using our new method, called long-distance genome-walking PCR (LDGW-PCR), extended fragments up to $4.0 \mathrm{~kb}$ have been obtained. In addition, the reliability of this technique is high.

Most of our work has been on the hexamerin gene of the mosquito (Anopheles gambiae), which will be described in detail; we also studied the hairy gene in Drosophila. Genomic DNA was extracted from a single mosquito or Drosophila using Protocol 1 of the Easy-DNA ${ }^{\mathrm{TM}}$ Kit (Invitrogen, Carlsbad, CA, USA) according to the manufacturer's manual.

Three primers are needed for gene walking: two primers specific to the $3^{\prime}$ end of the known sequence (SP1: 5'TCA TCA TCA CGC CGT ACA CGG C-3'; SP2: 5'-CGC TTC TAC GAC AGC CTG CCG TTC-3') and an adapter primer [AP; EcoRI-(G) $15: 5^{\prime}$ CGA GGA ATT CGG GGG GGG GGG GGG G-3'], which contains an EcoRI site near its $5^{\prime}$ end. For internal sequence probe, two additional specific primers were used (PKM122 + 21: $5^{\prime}$ -
GGA TAT CCG TTC GAT CGC TCA3'; PKM122 - 300: 5'-CAC TAG AAG CGA CCG AGA GAG-3’). PKM122 + 21 is located 10 bases downstream from SP2. PKM122 - 300 is located 300 bases downstream from the $3^{\prime}$ terminus of the hexamerin gene (3'-flanking region).

The new method has three steps (Figure 1). The extension reaction was performed to extend single-stranded (ss)DNA of target sequence using one primer (SP1). The reaction mixture contains $1 \times$ LA-PCR buffer [40 mM Tricine-KOH (pH 9.2; Catalog No. 8417-1; CLONTECH Laboratories, Palo Alto, CA, USA), $3.5 \mathrm{mM}$ magnesium acetate, $15 \mathrm{mM}$ potassium acetate, $75 \mu \mathrm{g} / \mathrm{mL}$ bovine serum albumin (BSA)], $0.2 \mathrm{mM}$ of each dNTP, 50 pmol of SP1, $50 \mathrm{ng}$ mosquito genomic DNA and 2.5 U KlenTaq polymerase (CLONTECH) in a final reaction volume of $50 \mu \mathrm{L}$. Thermal cycling was performed using a PCR System 9600 DNA Thermal Cycler (Perkin-Elmer, Norwalk, CT, USA) with the following conditions: $96^{\circ} \mathrm{C}$ for $10 \mathrm{~s}, 64^{\circ} \mathrm{C}$ for $10 \mathrm{~s}$ and $68^{\circ} \mathrm{C}$ for 4 min for 35 cycles.

The primer extension products were purified using GENECLEAN ${ }^{\circledR}$ III (BIO 101, Vista, CA, USA) and adjusted to a volume of $10 \mu \mathrm{L}$. The purified amplification product was incubated for $5 \mathrm{~min}$ at $95^{\circ} \mathrm{C}$ in a water bath and chilled immediately on ice for 2 or 3 min. For tailing, $4 \mu \mathrm{L}$ of $5 \times$ tailing buffer (1 M potassium cacodylate, 125 $\mathrm{mM}$ Tris- $\mathrm{HCl}, 1.25 \mathrm{mg} / \mathrm{mL}$ BSA, $\mathrm{pH}$ 6.6), $3 \mu \mathrm{L}$ of $5 \mathrm{mM} \mathrm{CoCl}_{2}, 1 \mu \mathrm{L}$ of 100 pmol dCTP and $50 \mathrm{U}$ of terminal deoxyribonucleotidyl transferase (TdT; Boehringer Mannheim, Indianapolis, IN, USA) were added, and the mixture was incubated for $20 \mathrm{~min}$ at $37^{\circ} \mathrm{C}$ followed by heating for $10 \mathrm{~min}$ at $70^{\circ} \mathrm{C}$. The reaction mixture was diluted to 100 $\mu \mathrm{L}$ in distilled water, and $1-5-\mu \mathrm{L}$ aliquots were used for PCR.

PCR was performed using two primers (SP2 and AP) with the following conditions: $96^{\circ} \mathrm{C}$ for $30 \mathrm{~s}, 65^{\circ} \mathrm{C}$ for $10 \mathrm{~s}$ and $68^{\circ} \mathrm{C}$ for $5 \mathrm{~min}$ for 40 cycles followed by a 5-min incubation at $68^{\circ} \mathrm{C}$. Longer denaturation time was applied to the second reaction than to

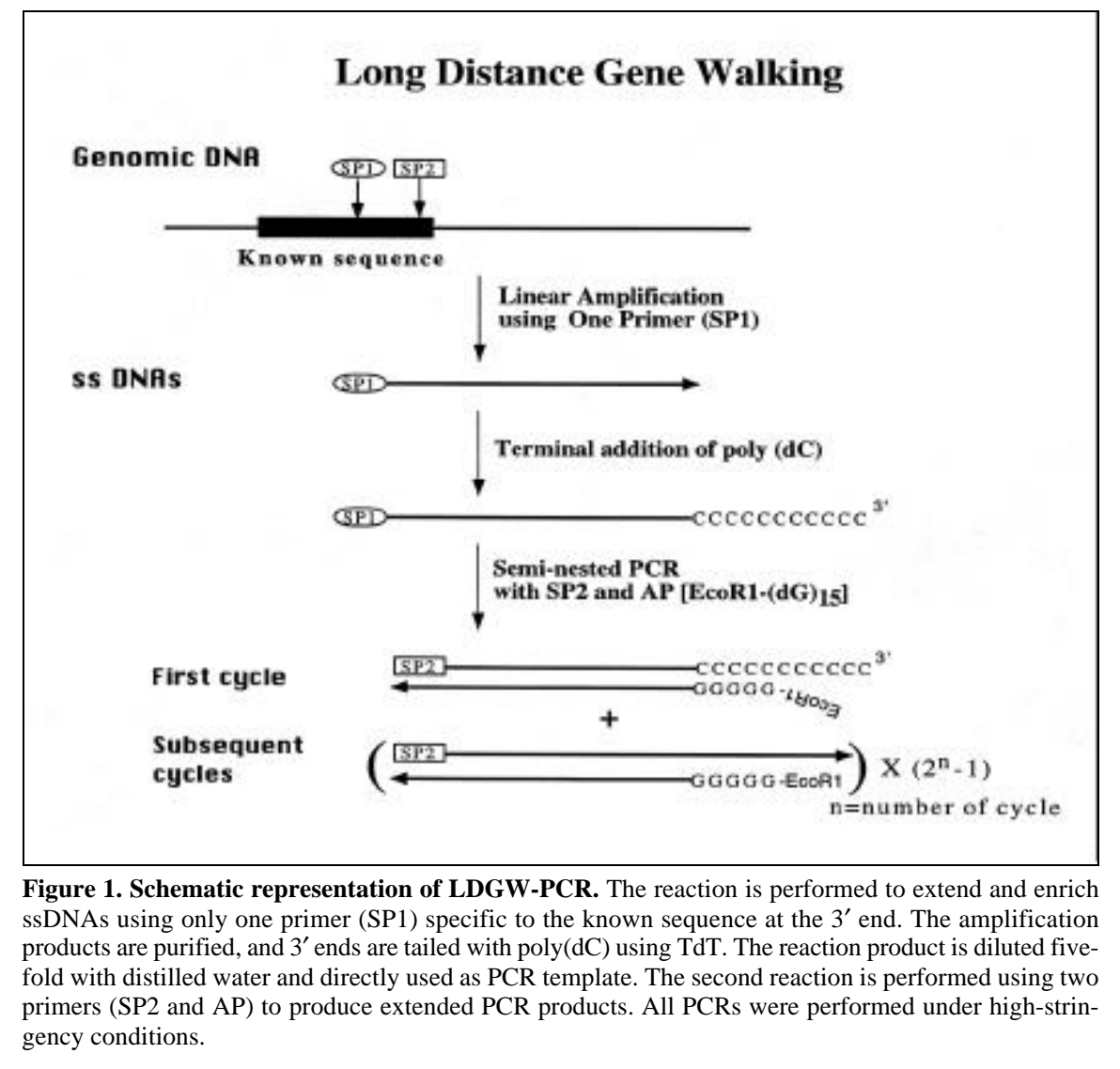


Table 1. Results of Six Consecutive Attempts at Gene Walking Using LDGW-PCR

\begin{tabular}{|lcccc|}
\hline Species & Gene & Direction & Time (min) & Length (kb) \\
\hline A. gambiae & Hexamerin & $3^{\prime} \rightarrow 5^{\prime}$ & 4 & 3.8 \\
A. gambiae & Hexamerin & $3^{\prime} \rightarrow 5^{\prime}$ & 4 & 4.0 \\
A. gambiae & Hexamerin & $5^{\prime} \rightarrow 3^{\prime}$ & 2 & 2.5 \\
A. gambiae & Hexamerin & $5^{\prime} \rightarrow 3^{\prime}$ & 2 & 1.5 \\
$\begin{array}{ll}\text { D. nebulosa } \\
\text { D. willistoni }\end{array}$ & $3^{\prime} \rightarrow 5^{\prime}$ & 4 & 4.2 \\
The hexamerin gene was studied in the mosquito A. gambiae, and the hairy gene \\
was studied in two species of Drosophila. "Time" is the polymerization time of the \\
first reaction. "Length" is the approximate size of the largest discrete band detect- \\
ed on an agarose gel that was subsequently sequenced and confirmed to be an \\
accurate extension of the known sequence. \\
\hline
\end{tabular}

the first to denature the AP primer [including poly(dG) tail] completely. Also, twice the amount of KlenTaq polymerase (5 $\mathrm{U}$ for each tube) was used in the PCR, and an additional aliquot of polymerase (1-2 $U$ for each reaction tube) was added during the denaturation step of the 30th cycle.

To confirm that we produced extended fragments, Southern blot analysis and sequencing were performed. DNA molecular weight marker (1-kb ladder) and PCR products were loaded onto a $1.0 \%$ agarose gel containing ethidium bromide. DNA fragments were trans-

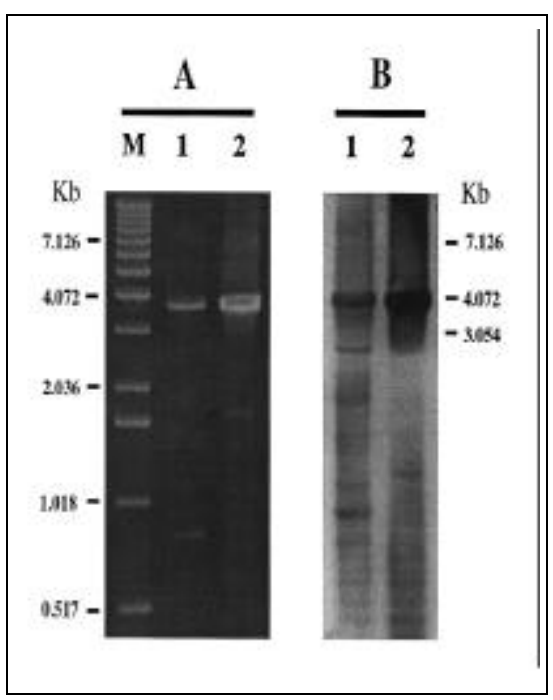

Figure 2. Genome walking products from LDGW-PCR. Amplification products were obtained using primers SP2 and AP. (A) Agarose gel stained with ethidium bromide. Lane $\mathrm{M}$ : DNA molecular weight marker (1-kb ladder). Lanes 1 and 2: PCR products obtained from two replicates of the initial extension reaction. (B) Southern blot analysis using internal sequence probe of the same gel. ferred to a Hybond ${ }^{\mathrm{TM}}-\mathrm{N}$ membrane (Amersham International plc, Little Chalfont, Bucks, England, UK). Digoxigenin-labeled internal nucleotide sequence (Random-Primed DNA Labeling method; Genius ${ }^{\mathrm{TM}} 1 \mathrm{Kit}$; Boehringer Mannheim) was used as a probe. Hybridization was performed overnight at $48^{\circ} \mathrm{C}$ in hybridization solution: $50 \%$ formamide, $5 \times$ standard saline citrate (SSC), 2\% (wt/vol) blocking reagent (Boehringer Mannheim), 0.2\% sodium dodecyl sulfate (SDS) and $0.1 \% \mathrm{~N}$-lauroylsarcosine. The membrane was washed twice for $15 \mathrm{~min}$ at $68^{\circ} \mathrm{C}$ in $0.5 \times$ SSC with $0.1 \%$ SDS.

The two largest PCR products (about $4.0 \mathrm{~kb}$ ) were isolated from a $1.2 \%$ low-melting agarose gel and purified by GENECLEAN III. Both purified fragments were sequenced using the cycle sequencing protocol with dyelabeled dideoxyribonuclotides on a Model 373A DNA Sequencer (PE Applied Biosystems, Foster City, CA, USA). The quality of the product was sufficient to produce $400 \mathrm{bp}$ or more of accurate sequence per sequencing reaction. The purified fragments were also cloned into the TA Cloning ${ }^{\circledR}$ vector using the TA Cloning Kit (Invitrogen). Cloned plasmids were purified by the QIAGEN ${ }^{\circledR}$ Plasmid Mini Kit (Qiagen, Chatsworth, CA, USA) and sequenced.

Using this technique, numerous bands were obtained per reaction, and nearly all the bands between 2 and $4 \mathrm{~kb}$ appeared to be specific gene sequences from Southern blot analysis (Figure 2). However, two small bands, 0.5-2.0 kb, appeared in the agarose gel but were not detected in Southern blot analysis. 


\section{Benchmarks}

Therefore this gene-walking technique accurately amplifies longer fragments (3-4 kb) while some of the shorter ones $(<2 \mathrm{~kb}$, Figure 2) might be artifacts. Furthermore, larger bands (5-7 kb) could also be detected by both Southern blot and agarose analyses, although the bands were too weak to detect easily.

Because the SP2 primer was about $350 \mathrm{bp}$ from the $3^{\prime}$ end of the known sequence, this provides an internal control for artifacts. In sequencing both the 3.5 - and $4.0-\mathrm{kb}$ products, we confirmed that these fragments are true extensions of the known region because the first $350 \mathrm{bp}$ of the $5^{\prime}$ ends of both are identical to the known $3^{\prime}$ ends.

The reliability of the technique is high. Once having worked out the initial conditions and procedures, we have not had a failure in six attempts at walking for both the mosquito hexamerin gene and the Drosophila hairy gene (Table 1). Walking in both the $3^{\prime}$ and $5^{\prime}$ directions is possible by simply using alternative strands. Another aspect of the length of the walk suggested by Table 1 is that the length of the product is dependent on the polymerization time during the thermal cycling. One somewhat unexpected result is that there is one predominant discrete band (Figure 2). This is probably not due to any secondary structures because, as can be seen in Table 1, the size of the predominant product is a function of time of polymerization. Furthermore, we have sequenced multiple clones from the discrete band that vary in size by $100-200 \mathrm{bp}$, so while the band appears discrete, it contains molecules that vary in size.

\section{REFERENCES}

1.Balavoine, G. 1996. Identification of members of several homeobox genes in a planarian using a ligation-mediated polymerase chain reaction technique. Nucleic Acids Res. 24:1547-1553.

2.Barnes, W.M. 1994. PCR amplification of up to 35-kb DNA with high fidelity and high yield from lambda bacteriophage templates. Proc. Natl. Acad. Sci. USA 91:2216-2220.

3.Cheng, S., C. Fockler, W.M. Barnes and R. Higuchi. 1994. Effective amplification of long targets from cloned inserts and human genomic DNA. Proc. Natl. Acad. Sci. USA 91:5695-5699.

4.Domínguez, O. and C. Lopéz-Larrea. 1994. Gene walking by unpredictably primed PCR.
Nucleic Acids Res. 22:3247-3248.

5.Frohman, M.A., M.K. Dush and G.R. Martin. 1988. Rapid production of full-length cDNAs from rare transcripts: amplification using a single gene-specific oligonucleotide primer. Proc. Natl. Acad. Sci. USA 85:89989002.

6.Loh, E.Y., J.F. Elliott, S. Cwirla, L.L. Lanier and M.M. Davis. 1989. Polymerase chain reaction with single-sided specificity: Analysis of T-cell receptor $\delta$ chain. Science 243:217-220.

7.Malo, M.S., K. Srivanstava, J.M. Andersen, X. Chen, J.R. Korenberg and V.M. Ingram. 1994. Targeted gene walking by low stringency polymerase chain reaction: assignment of putative human brain sodium channel gene (SCN3A) to chromosome 2q24-31. Proc. Natl. Acad. Sci. USA 91:2975-2979.

8.Ochman, H., A.S. Gerber and D.L. Hartl. 1988. Genetic applications of an inverse polymerase chain reaction. Genetics 120:621-623.

9.Parker, J.D., P.S. Rabinovitch and G.C. Burmer. 1991. Targeted gene walking polymerase chain reaction. Nucleic Acids Res. 19:3055-3060.

Supported by grants from the USPHS, National Institutes of Health and the $\mathrm{Na}$ tional Science Foundation. Address correspondence to Jeffrey R. Powell, Department of Ecology and Evolutionary Biology, 165 Prospect St. OML 427, Yale University, New Haven, CT 06520-8106, USA. Internet: jeffrey.powell@yale.edu

Received 21 April 1997; accepted 3 November 1997.

\section{Gi-Sik Min and Jeffrey R. Powell \\ Yale University \\ New Haven, CT, USA}

\section{ADDENDUM}

The following is an addendum to a June 1995 BioTechniques article; Shapiro, M., 1995, DNAdraw: A Program for Preparing DNA and Protein Data for Publication, 18 : 1064-1067.

An update of the DNAdraw software described is now available at the DNAdraw Web site (http:// www.cvn.net/ dnadraw). The new Version 3.0 represents a major upgrade, with additional features including direct printing, color output, optional page breaks and lots more. It can be downloaded from the Web site.

\section{Relative Amplification Efficiency of Differently Sized Templates by Long- Distance PCR}

\section{BioTechniques 24:400-402 (March 1998)}

A common concern with polymerase chain reaction (PCR) is the variation of amplification efficiency with template size. Length-dependence problems can arise when amplifying differently sized alleles (2), pseudogenes (6) or heterogeneous genomes involving deletions $(4,5)$. In conventional PCR, smaller fragments are more efficiently amplified than significantly larger templates. However, accounts of long-distance (LD)-PCR amplifying smaller fragments preferentially, albeit to a lesser extent than conventional PCR $(4,5)$, remain controversial (6). This work evaluates the quantitative relationships between template size and LD-PCR amplification efficiency.

Defined quantities of templates of different sizes were co-amplified with a constant amount of a reference template. PCR targets were complete or deleted human immunodeficiency virus type 1 (HIV-1) genomes cloned into pUC and AatII-linearized (5). HIV-1 genome sizes were 9709 bp (pNL4-3; Reference 1), 4313 bp (p $\Delta$ nipdj; Reference 5), 2693 bp (p $\Delta$ focep; Reference 5) and 1948 bp (p $\Delta$ cesmo; Reference 5). Two distinct sets of primers were used for amplification: primers LTR U5/LTR R (Figure 1) yielded products of 9.1, 3.6, 2 and $1.3 \mathrm{~kb}$ with targets pNL4-3, p $\Delta$ ni$\mathrm{pdj}, \mathrm{p} \Delta$ focep and $\mathrm{p} \Delta$ cesmo, respectively, while primers CL-NCS and CL-NEF (5'-ATCTCTCGACGCAGGACTCGGCTTGCTGAA-GCGCGCA-3' and 5'CCATGTTTTTCTAGGTCTCGAGATACTGCTCC-3', respectively) yielded products of $8.2,2.8,1.2$ and $0.4 \mathrm{~kb}$. Templates were subjected to LD-PCR with $1.75 \mathrm{U}$ of Expand ${ }^{\mathrm{TM}}$ Long-Template PCR enzyme (Boehringer Mannheim, Meylan, France) in a 50- $\mu \mathrm{L}$ reaction mixture containing $50 \mathrm{mM}$ Tris$\mathrm{HCl}, \mathrm{pH} 9.2,14 \mathrm{mM}\left(\mathrm{NH}_{4}\right)_{2} \mathrm{SO}_{4}, 1.75$ $\mathrm{mM} \mathrm{MgCl} 2,350 \mu \mathrm{M}$ each dNTP, 7.5 pmol of each primer and $100 \mathrm{ng}$ of human genomic DNA carrier. Templates were amplified with 25 cycles at $94^{\circ} \mathrm{C}$ 